\title{
Undagi Bali Ethnomathematic Study and How to Acquire Its Knowledge
}

\author{
I P P Suryawan* and M Juniantari
}

\begin{abstract}
Department of Mathematics, Faculty of Mathematics and Sciences, Universitas Pendidikan Ganesha, Singaraja-Bali. *Corresponding author. Email: putu.pasek@undiksha.ac.id
\end{abstract}

\begin{abstract}
The purpose of this research was to find out: (1) ethnomatematics at Undagi Bali in Penglipuran Village; and (2) how Undagi Bali knows and gets knowledge about Undagi Bali ethnomatematics in Penglipuran Village. This research is a qualitative research using exploratory method, with data collection methods using literature study, observation, and interviews. The subjects of this research are people who work as Undagi traditional Balinese buildings in Penglipuran. The results of the exploration show that there are several ethnomatics in Undagi Bali, namely body measurements such as "lengkat, depa, tampak, ahasta, amusti", as well as making house roof trusses, building house foundations, and making "lulu/sludge" . The ethnomatematics obtained are related to concepts in formal mathematics, such as counting, measuring, and counting activities. The process of the Undagi gaining knowledge is by learning to imitate the more experienced Undagi, learning basic concepts through literature, and learning from their own experiences.
\end{abstract}

\section{Keywords: Ethnomatematics, Balinese Undagi, Traditional Building}

\section{INTRODUCTION}

The relationship between mathematics and culture is contained in ethnomatematics. Ethnomatematics is an intersection between ethnographic studies, ethno modeling, and mathematics itself [1]. Ethnomatematics is the science of numbers and manipulation embedded in the culture of society. Geometric concepts like squares, rectangles, circles, straight lines, angles, parallel and perpendicular lines, and lines of symmetry are embedded in cultures such as mats, houses, fish traps and so on [2]. The definition proposed on reff [3] states that "I have using the word ethnomathematics as modes, styles, and techniques (tics) of explanation of understanding and of coping with the natural and cultural environment (mathema) in distinct cultural systems (ethnos)". This means that etnomatematika can be used as fashion, style, and techniques to explain, understand, and face the natural and cultural environment in a different culture system. Etnomatematika aimed to recognize that there are different ways of doing mathematics by considering academic mathematical knowledge developed by different sectors of society where different cultures enables different mathematical practices [4]. In other words, ethnomatematics can be a solution to bring formal mathematics closer to students. Ethnomathematics strongly supports the improvement of people's understanding of mathematics through the culture around it, because the environment is the main pattern-maker and understanding for society [5]. This is also supported by several previous studies related to ethnomatematics. Research conducted on reff [6] discusses the ethno mathematics of the Badui community which states that the mathematical way of thinking understood by the Badui community is a form of non-formal, simple, logical mathematics that can support their lives. Furthermore, research conducted on reff [7] showed that the use of ethnomathematic teaching materials with cups and broth plates on the volume half ball and tube material increased student achievement in mathematics. In addition, the author himself once studied more deeply the integration of ethnomatematics in the Tembuku sub-district, Bangli-Bali district in mathematics learning [8]. Some of these studies show that mathematics is already related to the culture that exists in each region, and in its application in the classroom, ethno-mathematics has a positive impact on learning mathematics.

Based on the description above, ethnomatematics can be one of the important things to be used as material for a more in-depth study, because culture is a bridge that can connect society and students with mathematics [9],[10]. 
Ethnomatematics can also be an alternative for people and students to better understand mathematics [11]. Therefore, it is very important to examine deeply the ethnomathematics contained in other fields in order to enrich the nuances of mathematics contained in culture, which will later serve as a source of meaningful and innovative mathematics learning [12]. One of the interesting cultures to study which contains ethnomatematics is the traditional carpentry culture by Undagi Bali [13]. In fact, currently there are many researchers who have started to develop ethnomatematics in various regions, but there is still no comprehensive research discussing ethnomatematics related to Undagi Bali woodworking culture, especially Undagi who works on traditional Balinese buildings, such as traditional Balinese buildings in Penglipuran Village Bali Regency. This ethnomatics will provide benefits to the community, because in Penglipuran Village the community is still close to the activities carried out by Undagi Bali, with proven patterns and forms of buildings in Penglipuran Village that remain steady and constitute local wisdom which is the main attraction for tourists.

Penglipuran Traditional Village is a traditional settlement in Bali which has an interesting spatial pattern seen from the unique spatial patterns of the cultural activities of its people [14]. Penglipuran Village as a settlement has a spatial pattern which is divided into three spatial divisions based on the Tri Mandala concept which consists of: (1) Utama Mandala (Temple); (2) Madya Mandala (Residence); and (3) Nista Mandala (Tomb). The Penglipuran Balinese Traditional House is an order/form of the cultural thought patterns of the ancestors of the Penglipuran people who organize an area well, uphold ancestral customs and strive to maintain the order neatly, regularly, and still have a concept of being sustainable with nature and the surrounding environment [15]. Figure 1 below illustrates the condition of traditional buildings in Penglipuran Village that were made directly by Undagi Bali from the local village [15].

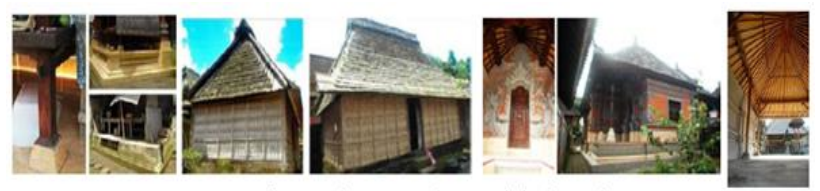

Figure 1. Types of Balinese Traditional Buildings in Penglipuran Village

Undagi in Penglipuran Village uses natural building materials that can be taken from their environment as the main building material. This natural material can be seen in many traditional buildings in villages [16]. Most traditional Balinese houses are made from organic materials such as wood, bamboo, thatch, and plant fibers [17]. The results of field observations on residential houses and literature studies concluded that uniform material choices were found in their dwellings. The house on stilts in Balinese houses has been replaced by a brick courtyard, similar to that of the courtyard in a temple [18]. The meeting of poles and wooden beams in a building in Penglipuran Village, Bali, the character of the beam usually does not stop at the column, but is made about 10 $\mathrm{cm}$ longer than the pole.

The uniqueness of traditional buildings in Penglipuran Village is certainly not separated from the traditional Undagi Bali carpentry techniques, so it is very interesting to study the mathematics contained in Undagi Bali's woodworking culture in the form of Undagi Bali ethnomatematic studies in Penglipuran Village. This research is a qualitative research, which will explore the ethnomatematics of Undagi Bali in Penglipuran Village and how the culture can remain steady until now, including how the community gets knowledge related to Undagi Bali ethnomatematics. The knowledge related to Undagi Bali that will be explored is related to the way of thinking that the masons have in applying existing knowledge related to the manufacture of traditional Balinese buildings with the ethnomatematics in them. This knowledge is knowledge that has been around for a long time, so this knowledge may be informal but it is well known to many people.

Based on the problem above, it is necessary to do a research to obtain and develop mathematics teaching materials. Related to the aforementioned background, the question addressed in this study was "(1) what are the mathematical elements contained in the ethnomatematics of Undagi Bali in Penglipuran Village? and (2) how do people who work as Undagi Bali in Penglipuran Village know and get knowledge about Undagi Bali ethnomatematics?

\section{METHODOLOGY}

This research has a main focus on ethnomatematics, so the research was conducted in Penglipuran Village, Bangli Regency. The researcher took the subject, namely some Undagi Bali in the local village. In addition, researchers also dig up information through experts in the fields of Balinese traditional buildings, traditional leaders, and traditional village buildings.

This research uses qualitative research methods with exploration. The reason the researcher uses qualitative research methods is because the problems are still complex, dynamic and full of meaning so that it is impossible for data on these social situations to be captured by quantitative research methods [19].

In addition, researchers intend to understand social situations in depth, find patterns, hypotheses, and theories [20]. Thus, the emphasis lies on the understanding that arises from the interpretation of interactions, behaviors and events. With exploration, researchers can also get data related to Undagi Balinese culture in Penglipuran Village more flexibly.

In qualitative research, the main instrument is the researcher himself [21]. Qualitative researchers as a human instrument whose function is to determine the focus of research, select informants as data sources, collect data, assess data quality, analyze data, interpret data and make conclusions on their findings [22]. Data collection 
related to Undagi Bali ethno-mathematics was carried out by means of observation, interview and documentation techniques. Data collection is carried out in natural settings (natural conditions), primary data sources, and data collection techniques are more on participatory observation (praticipan observation), in-depth interviews (in depth interviews), and documentation [21].
The data analysis carried out in this study was in accordance with the data analysis stages proposed by Spradley [22], namely domain analysis, taxonomic analysis, component analysis, and cultural theme analysis. The plot can be described in Figure 2 below.

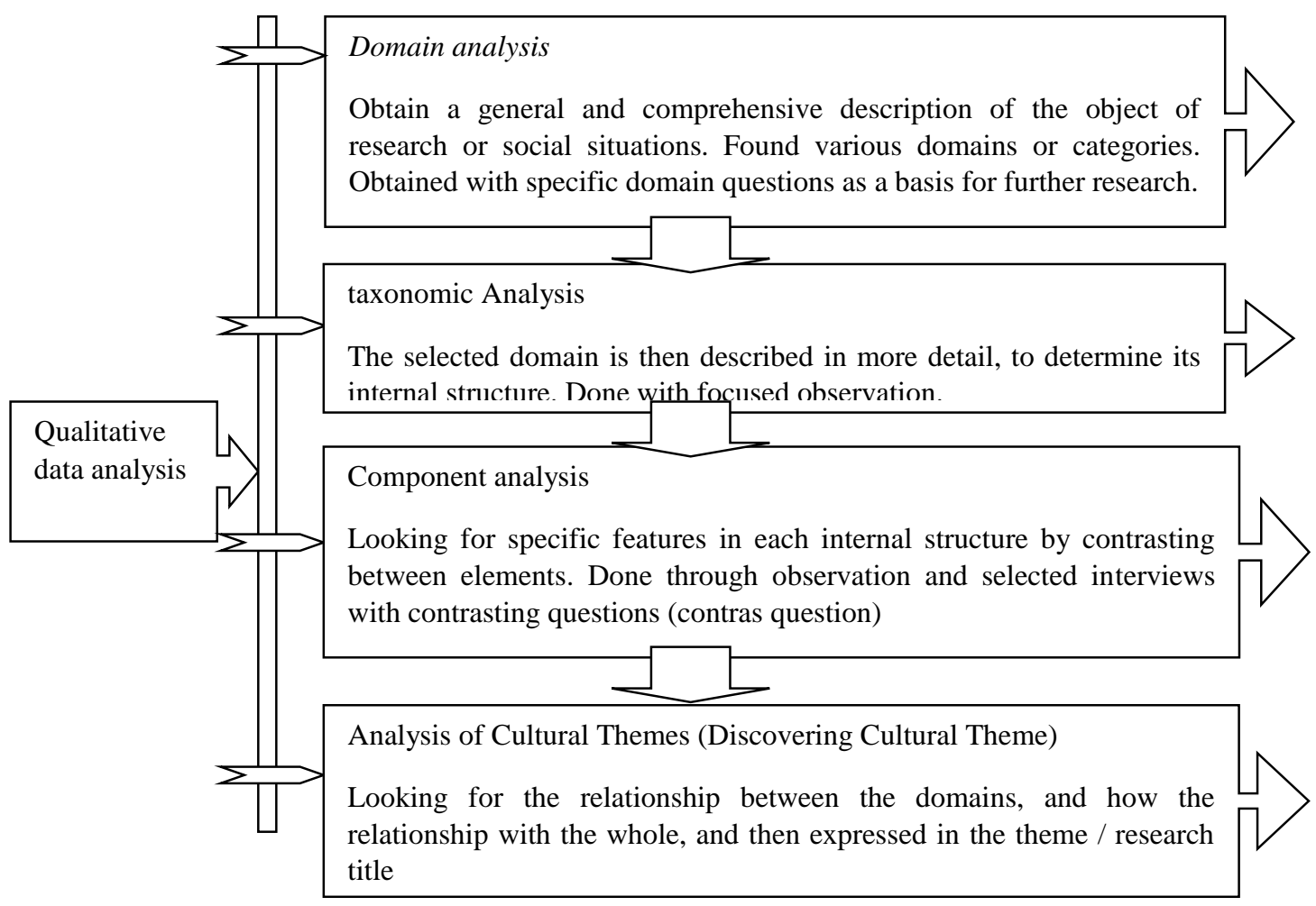

Figure 2. Types of Qualitative Data Analysis [22]

\section{RESULTS AND DISCUSSION}

\subsection{Results}

In this research, domain analysis, taxonomic analysis, compositional analysis, and cultural theme analysis were carried out. Domain analysis is the first step in qualitative research [24]. Through this analysis, it is found that an overview of the process of making traditional Balinese buildings in Penglipuran village is found. There are various domains on which this research is based, as shown in Table 1 below.
Table 1. Results of Undagi Bali Ethnomatic Domain Analysis

\begin{tabular}{|c|c|c|}
\hline $\begin{array}{c}\text { Domain } \\
\text { Details }\end{array}$ & $\begin{array}{l}\text { Semantic } \\
\text { Relations }\end{array}$ & Domain \\
\hline Language & Is jargon & $\begin{array}{l}\text { Used as a tool to simplify } \\
\text { calculations in making } \\
\text { traditional Balinese } \\
\text { buildings }\end{array}$ \\
\hline $\begin{array}{l}\text { Knowledge } \\
\text { System }\end{array}$ & A habit & $\begin{array}{l}\text { The non-formal habits used } \\
\text { in the making of traditional } \\
\text { Balinese buildings }\end{array}$ \\
\hline $\begin{array}{l}\text { Religious } \\
\text { System }\end{array}$ & $\begin{array}{l}\text { Is the } \\
\text { applicable rules }\end{array}$ & $\begin{array}{l}\text { The rules that apply to the } \\
\text { manufacture of traditional } \\
\text { Balinese buildings are } \\
\text { believed to have a bad } \\
\text { impact if they are violated }\end{array}$ \\
\hline
\end{tabular}


After obtaining this general description, a taxonomic analysis is then carried out. In this analysis, a search is made for how the domain is described in more detail with focused observation. Obtain more detailed information related to all existing domain. In the language domain, it is found that there are several languages which in ethnomathematics can be called jargon, which when digging deeper turns out to have meaning in calculations. Like the term "ping" which means to double, then also the term "nikel" which means to double the count. Then the calculation of numbers in local languages, such as besik, dua, telu, and so on. In the domain of the knowledge system, data is obtained about what knowledge. Undagi Bali has and how they apply knowledge related to the making of traditional Balinese buildings. Knowledge was also gained from the literature through the study of literature. So in this domain information is obtained about the knowledge contained in the making of traditional Balinese buildings, both formal and informal. One of the knowledge gained is how to manufacture various parts of traditional Balinese buildings and how to calculate and measure them Then in the domain of the religious system, it is related to the beliefs held by the Balinese people. Data acquisition is from interviews and literature studies. There are various calculations that must conform to the general belief, because if it is not followed then believed to homeowners and all those who stay at home will be hurt.

Furthermore, a comparative analysis is carried out wherein this analysis is carried out a search for the specific features of each internal structure by contrasting between elements through selected observations and interviews. After obtaining various data from various sources, the researcher then looks again at which data if necessary, and if different. The data are then made more specific and contrasted. At this stage, a triangulation process is carried out between the data obtained from different Undagi, architects, traditional leaders, traditional bendes, and literature. Data that has quite a contrast is how to determine the location of the gate and how to make a rectangular shape.

The last is an analysis of cultural themes whose activity is to look for relationships between domains, and how they relate to the whole in an effort to find a "common thread". Based on this analysis, it is found that between all domains namely language, knowledge systems, and religion are interrelated. All of these are the basis for making traditional Balinese buildings. Undagi knowledge is used to carry out the construction of traditional Balinese buildings correctly, where the construction uses various jargon or related terms and the manufacture must be in accordance with applicable religious rules.

Based on the description of the domain above, with the limited space and time given due to the closed access to Penglipuran Village as a result of the Covid-19 pandemic, for the time being the researchers focused on interviews related to the making of Umah Paon in Penglipuran Village. The display of umah paon in Penglipuran Village is as shown in Figure 3 below.

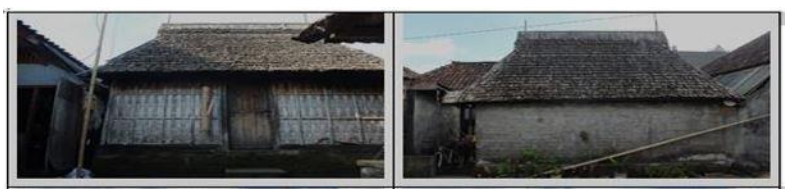

Figure 3. Documentation of Umah Paon in Penglipuran Village

There are many mathematical activities in community building activities in Penglipuran Traditional Village. Ethnomathic activities are counting activities, measuring activities, calculating activities. In more detail, here are the ethnomatematic activities contained in the activities of building Umah Paon in Penglipuran Traditional Village.

1) Counting Activity

Counting activities appear in various activities to build a house, because almost every activity to build a house requires measurements and calculations that involve mathematical numbers. This counting activity concerns the mention of numbers, including the mention of the principal number (se, due, telu, ..., dase). The activity of mentioning the standard unit by mentioning the preposition (centi $(\mathrm{cm})$, meter $(\mathrm{m})$, square meter $(\mathrm{m} 2)$, kibik (m3), kilo (kg).Counting activity when mixing "luluh/sludge" involves comparative mathematics, but the builder (Undagi) does not directly mention that mixing coral, sand and cement is $3: 2: 1$. The builder called it telu dua sik. The use of "ping" jargon is associated with repeated summation ("nem ping telu" is $6+6+6)$. The use of "nikel" jargon related to doubling ("nem nikel ping telu" is six folded three times).

2) Activity Measuring

Measurements used to build the house, including meter measurements, water hoses, lots, waterpass, and rulers. In building a house it cannot be separated from measuring activities, because almost all activities require measurement. The activity of measuring the corner of the house using a rope involves mathematics, namely the Pythagoras Theorem. How to make right ruler traditionally with rope and wood. In this way, Undagi uses the size of $60 \mathrm{~cm}, 80 \mathrm{~cm}, 100 \mathrm{~cm}$ without knowing that it is a triple phytagoras. The activity of measuring the length and width of the soil will be used to sketch a room, and in sketching involves comparative mathematics. Measuring the foundation also involves comparative mathematical knowledge of value, the higher the house, the deeper the foundation will be. The activity of measuring the length of wood for the truss of a house involves comparative mathematics, because before measuring wood, a builder makes a sketch related to the length of the wood. 
Furthermore, in addition to interviews, observation activities were also carried out to Undagi. Observations to Undagi conducted to confirm the results obtained from the relevant literature and to obtain information related to etnomatematika Undagi Bali and elements in Undagi which has a mathematical value. A more detailed explanation regarding the observation results will be presented as follows.

Based on the results of observations on Undagi, information is obtained that there are several basic scales of Balinese measurement used in the process of making traditional Balinese buildings, namely depa, alengkat, acengkang, acelek, atampak, atampakngandang, alek, akacing, ahasta, amusti, agemel, asirang, aguli tujuh, arahi, anyari, duang nyari, atampak lima, petang nyari, atebah tampak lima. All of these basic scales of measurement use the measurements of the human body, from head to toe of the house owner to be built.

With the development of the current era with the existence of length units such as meters or centimeters and the addition of carpentry tools such as meters, Undagi also followed the development of that era [14]. However, the Undagi also still uses traditional units as previously mentioned. The trick is to first measure these traditional measurements on the house owner's body and then convert them into length units as needed. So that the Undagi do not eliminate the elements of existing traditions and beliefs but collaborate with the times. These are the mathematical elements contained in the Balinese Undagi culture and the Balinese traditional buildings found in Penglipuran Bali Village which remain steady and not eroded by the times, and even become a special attraction for tourists as a local wisdom [15],[16].

\subsection{Discussion}

The knowledge that Undagi Bali has is knowledge related to how to make traditional Balinese buildings. This knowledge is mostly non-formal knowledge because most Undagi have not taken formal education and this knowledge is knowledge that has been around for a long time and is known by the next generation from generation to generation [7],[9].

Researchers got information about how Undagi got this knowledge through direct interviews with one of the Undagi named Astika. The following is a brief excerpt from the interview with Undagi Bali regarding how they got their current knowledge using the Balinese language, which is as follows.
"Tamat tiang masuk, langsung ade anak ane biase nukang to barengin tiang. Kije je barengin tiang. Ditu lantas tiang melajah ajak ane ngemalunin tiang, sambil tiang baange ngidih lontar-lontar. Melajah tiang uling ane bisaan, melajah tiang masih uling lontar-lontar, nika padaang tiang kanti makatang ilmune. Nyoba lantas tiang pedidi, kanti jani be bise didian. Mekelo to prosesne tiang mareng-marengin anak megae, tiang sing taen maan melajah nuking uli sekolah" (Astika, 2020).

Based on the quote, information was obtained that after Undagi finished his formal education, then he helped Undagi who were experienced in building houses. It took a long time to become a companion or assistant to finally be able to work independently because the knowledge that must be possessed regarding the making of Balinese buildings is not arbitrary. When he became a companion, he learned a lot about the methods used through direct activities with Undagi who was more experienced. The learning process was then also accompanied by reading various sources in the form of lontars. Then, after feeling that he had enough knowledge through direct learning and reading lontar, he finally dared to try independently [1],[3].

So, Undagi usually starts to pursue this traditional building carpentry by following Undagi who is more experienced when making the building, or it can be said to help the more experienced Undagi When helping out, Undagi who was just learning began to learn the methods used, the existing rules through the more experienced. Then after helping for several years and knowing the existing knowledge, Undagi started to try himself and read some literature such as lontars which contained knowledge about the activities of making traditional Balinese buildings. Then after they had enough knowledge, Undagi started trying to be independent without following the more experienced Undagi. The mistakes they get while trying to be independent then also become part of the knowledge they currently have.

Getting into the profession as Undagi Bali is not an easy thing and can be done by everyone. People who are in this profession usually have their own talents and interests in this profession so it will be easier and more determined when they learn it. The process of decreasing knowledge itself since ancient times is almost always the same. It starts with getting the new person to work together and then also giving the new person their resources. When these collaborative work activities are carried out, at that time Undagi who is more experienced will provide methods that are often used when building buildings and directly link them to the information contained in lontar sources. So it can be said that the knowledge they have has become like a habit [9]. 
Based on this explanation, it can be concluded that the Undagi process of gaining knowledge is by learning to imitate or learn through examples in Undagi who are more experienced, then learn basic concepts through various literatures, and also learn from their experiences when they are independent. Until now, when Undagi is used to working independently, they still make small mistakes and are still learning. Based on the description above, the results of this study support and are in line with the results of [16] which states that the Penglipuran Balinese Traditional House is an order / form of cultural thought patterns of the ancestors of the Penglipuran people who organize an area well, upholding ancestral customs. as well as striving to maintain this order in a neat, orderly manner, and still have a concept of being sustainable with nature and the surrounding environment. The concurrency was obtained because Undagi who built the house came from Penglipuran Village himself and unwittingly reproduced the mathematical concept to build traditional buildings so that they remain strong and well patterned. In addition, the results of this study are also in line with the results of [15] which states that the wisdom of the people of Penglipuran Village, Bangle Regency in preserving bamboo plants and its application as traditional building materials, especially Pawon houses. With the skills of the Undagi in Penglipuran village in applying mathematics which he had never realized, he made bamboo in the Penglipuran area useful for building Pawon houses and as one of the tourist objects and attractions of its own. Thus, it can be concluded that Undagi Bali in Penglipuran village is a group of people who have their own culture and have unwittingly applied mathematics in building traditional Balinese buildings such as counting, counting, and measuring activities that lead to the work of traditional buildings which remain steady and not eroded by development era but it has become local wisdom [9].

\section{CONCLUSION}

Based on the results and previous discussion, it can be concluded that the mathematical elements contained in Undagi Bali mathematics in Penglipuran Village are in the form of counting, measuring, and counting activities. he knowledge that Undagi gained was through hereditary habits. They learn through seniors who already understand the process of making traditional Balinese buildings. Undagi also took formal education at least up to high school, so the knowledge they have is a collaboration from reading lontar, experience in the field, and knowledge gained from school. Undagi's process of gaining knowledge is by learning to imitate or learn through examples in Undagi who are more experienced, then learn basic concepts through various literatures, and also learn from their experiences when they are independent. Until now, when Undagi is used to working independently, they still make small mistakes and are still learning.

\section{ACKNOWLEDGMENT}

Thanks are conveyed to (1) LPPM Undiksha for the funding provided, and (2) the Penglipuran Village of Bangli Regency (Undagi, Bendesa Adat, Traditional Stakeholders, and the community) who have supported and facilitated the implementation of research so that the objectives of this research can be achieved optimal.

\section{REFERENCES}

[1] M. Rosa, D. C. Orey. Ethnomodeling as a research theoretical framework on ethnomathematics and mathematical modeling. Journal of Urban Mathematics Education, 6 (2) (2013) 62-80.

[2] P. O. Abiam, O. S. Abonyi, J. O. Ugama, G. Okafor. Effects of ethnomathematics-based instructional approach on primary school pupils' achievement in geometry. Journal of Scientific Research and Reports, (2016) 1-15. DOI:https://doi.org/10.9734/JSRR/2016/ 19079

[3] R. D. Agustin, M. Ambarawati, E. D. E. D. Kartika. Ethnomatematika: Budaya dalam Pembelajaran Matematika. Laplace: Jurnal Pendidikan Matematika, 2 (1) (2019) 11-18. DOI:https://doi.org/10.31537/laplace .$v 2 \mathrm{i} 1.190$

[4] S. I. Hasanah, H. Lanya, C. F. Tafrilyanto, Z Aini. Implementation Of Mathematic Values Of Karapan Sapi's Madura With Stad Learning Settings In Sdn Pademawu. Pi: Mathematics Education Journal, 3 (2) (2020) 82-91. DOI:https://doi.org/10.21067/pmej.v3i 2.4774

[5] P. Gerdes. Reflections on ethnomathematics. For the learning of mathematics, 14 (2) (1994) 19-22.

[6] A. Arisetyawan, D. Suryadi, T. Herman, C. Rahmat, J. D. S. No. Study of Ethnomathematics: A lesson from the Baduy Culture. International Journal of Education and Research, 2 (10) (2014) 681-688.

[7] S. S. Unodiaku. Effect of ethno-mathematics teaching materials on students' achievement in mathematics in Enugu State. Journal of Education and Practice, 4 (23) (2013) 70-77.

[8] S. Hartinah, S. Suherman, M. Syazali, H. Efendi, R. Junaidi, K. Jermsittiparsert, U. M. A. M. Rofiqul. Probing-prompting based on ethnomathematics learning model: the effect on mathematical communication skill. Journal for the Education of Gifted Young Scientists, 7 (4) (2019) 799-814. DOI:https://doi.org/ $10.17478 /$ jegys.574275 
[9] N. I. S. Nasir, V. Hand, E. V. Taylor. Culture and mathematics in school: Boundaries between "cultural" and "domain" knowledge in the mathematics classroom and beyond. Review of research in education, 32 (1) (2008) 187-240. DOI:https://doi.org/10.3102/0091732 X07308962

[10] F. Favilli. Ethnomathematics and mathematics education: Proceedings of the 10th International Congress of Mathematics Education, discussion group 15: Ethnomathematics. Pisa, Italy: Tipografía Editrice Pisana.2007.

[11] R. E. Simamora, S. Saragih. Improving Students' Mathematical Problem Solving Ability and SelfEfficacy through Guided Discovery Learning in Local Culture Context. International Electronic Journal of Mathematics Education, 14 (1) (2019) 61-72. DOI :http s://doi.org/10.12973/iejme/3966

[12] W. M. Roth. Interdisciplinary approaches in mathematics education. Encyclopedia of mathematics education, (2020) 415-419. DOI:https://doi.org/10.10 07/978-3-030-15789-0_82

[13] Bidja, I Made. Asta Kosala-Kosali Asta Bumi. Pustaka Bali Post, Denpasar.2012.

[14] I. N. Suastika, G. P. A. J. Susila, N. M. A. Widiastini. Traditional Life Of Bayung Gede Community And Its Development As Cultural Attraction. International Journal Of Applied Sciences In Tourism And Events, 3 (1) (2019) 108-121. DOI: http:// dx.doi.org/10.31940/ijaste.v3i1.1227

[15] I. Priyoga, M. M. Sudarwani. Kajian Pola Ruang dan Rumah Adat Desa Penglipuran Bali. Prosiding Semarnusa IPLBI, (2018) 66-72. DOI:https://doi.org/ 10.32315/sem.2.a066

[16] W. Deng, J. Xie, Z. Peng. Material transitions and associated embodied energy input of rural buildings: case study of Qinyong village in Ningbo China .Sustainability, 10 (6) (2018) 2016. DOI:https://doi.or $\mathrm{g} / 10.3390 / \mathrm{su} 10062016$

[17] Julian, Davison. Balinese Architecture. Tuttle Publishing.2014.

[18] Sopandi, Setiadi. Sejarah Arsitektur Sebuah Pengantar. PT Gramedia Pustaka Utama, Jakarta.2013

[19] K. M. Benzies, M. N. Allen. Symbolic interactionism as a theoretical perspective for multiple method research. Journal of advanced nursing, 33 (4) (2001) 541-547. DOI :https://doi.org/10.1046/j.1365-26 48.2001.01680.x
[20] K. Yilmaz. Comparison of quantitative and qualitative research traditions: Epistemological, theoretical, and methodological differences. European journal of education, 48 (2) (2013) 311-325. DOI: https: //doi.org/10.1111/ejed.12014

[21] A. E. Pezalla, J. Pettigrew, M. Miller-Day. Researching the researcher-as-instrument: An exercise in interviewer self-reflexivity. Qualitative research, 12 (2) (2012) 165-185. DOI:https://doi.org/10.1177/1468 794111422107

[22] Sugiyono. Metode Penelitian Pendidikan. ALFABETA. Bandung.2016. 